intensity of the standard note is measured on a scale of decibels above an arbitrary zero near the threshold of hearing; the corresponding loudness is then expressed on a numerically identical scale of phons. The various subjective noise meters on the market determine the equivalent loudness of noises in phons by matching them by ear against the standard note. The objective meters, on the other hand, depend on the physical measurement of the intensity by a microphone; they can, however, be made to stimulate the ear and so compare the loudnesses of similar noises. The new acoustics laboratory at the National Physical Laboratory has greatly facilitated investigatory work on the steps required to reduce sources of noise, on the noise proofing of walls and on the noise absorption of building and other materials. The last line of defence against noise in a building is the use of surface absorbents. Ordinary hard plaster is a better reflector of sound than a mirror is of light, so that in modern rooms designedly free from curtains, upholstery and carpets, the noise level can become uncomfortably high unless one of the commercially available acoustic absorbents is applied to the walls or ceilings.

\section{Experimental Hand-Rearing of Game Birds}

ORNITHOLOGIsTs and students of game birds have become increasingly interested in experiments in hand-rearing and introducing game birds to new areas, and what is believed to be the first ptarmigan (Lagopus leucurus) to hatch in captivity was from one of eighteen eggs collected by Dr. A. A. Allen, of the Department of Ornithology of Cornell University, near Churchill, Hudson Bay, and put under bantams at Ithace (Scientific American, Nov. 1934). Science Service, of Washington, D.C., reports that a second batch of twenty ptarmigan eggs has been obtained from Canada and put under bantams, though several eggs have been broken by the foster mothers. During the present year, the first introduction, and hatching, of English pheasants (Phasianus colchicus) in Uganda was accomplished by the Agricultural Department at Kamala ( $T$. W. Chorley, Field, Aug. 4, 1934). The eggs were obtained by Mr. T. W. Chorley, of the Agricultural Department in Uganda, from the Silverdale Game Farm, Lancashire, and arrived by air mail on May 3. Next day they were put under two native fowls, and three chicks hatched on May 27, and the remainder on May 28, 85 per cent of the imported pheasant eggs hatching. Unfortunately, two heavy storms broke out in the first three weeks, and several birds died, but the remainder did well.

\section{Electricity on Board Ship}

THE paper read by C. W. Saunders, H. W. Wilson and Dr. R. G. Jakeman to the Institution of Electrical Engineers on November 22 on the generation, distribution and use of electricity on board ship is a timely one. Although electricity was used in the British Navy for various purposes so far back as 1874 , it is only since the advent of the Diesel engine that it has been largely used. To-day, almost all auxiliary machinery-from the windlass in the bows, through the engine room and hull, to the steering gear in the stern-is electrically operated in important ships. In a 20,000 ton turbo-electric passenger liner, the propelling machinery, usually two turbo alternators, would be about 20,000 horse power and there would be usually four motors to which they send the power. In addition, there would be four main generators each of a 1,000 h.p. The steering gear requires 84 h.p., the capstan machines 536 h.p. and the boat davits 120 h.p. For the fans 500 h.p. is required and for the refrigeration 290 h.p. Compared with these numbers, the $31 \cdot 5$ h.p. required for the passenger lifts seems small. A modern liner is really a large floating hotel, and when at sea the travelling public demands a standard of comfort as high as that obtainable on the best hotels ashore. Consequently the most modern types of lighting, heating and cooking equipment are installed. The galley alone at times of maximum load may require 900 h.p. In the Queen of Bermuda, for example, there is one 450 -line telephone board, 250 electric signs, 2,250 bell pushes, 400 electric radiators, 650 electric fans for cabins, 410 miles of conductors in cables and wires and 20,000 electric lamps. For very large ships it is generally agreed that turbo-electric drive is the most suitable at the present time.

\section{De la Beche's "Researches in Theoretical Geology"}

PUBLISHED in 1834, unpretentious in size and style (12mo.), De la Beche's work was especially welcome to the younger geologists of the time as a philosophical treatise, comprehensive and helpful in design. This little volume had an interesting preface explaining the author's position. It ran as follows:"Although the theory of central heat and the former igneous fluidity of our planet have been much dwelt upon in the following pages, the author trusts that he will not be considered so attached to these views as not to be ready to reject them and embrace others which may afford a better explanation of an equal number of unobserved facts. . . . It can only be amid a thousand errors, and by a determination to abandon our preconceived opinions, when shown to be untenable, not by pertinaciously adhering to them . . . that we can approximate towards the truth. By strictly advocating a particular theory, prominently displaying those facts only which may appear to afford it support, we are in perpetual danger of deceiving ourselves and others." Finally"We may conclude that whatever changes our planet may suffer, either from external or internal causes, and the necessary conditions exist, life will be created to suit those conditions; even after man, and the terrestrial animals and plants contemporaneous with him, may have ceased to live on the surface of the earth."

\section{Proceedings of the Fifth Pacific Science Congress}

Ix is hoped to publish very shortly the complete Proceedings of the Fifth Pacific Science Congress which was held at Victoria and Vancouver, Canada, in June 1933. The publication will be in five volumes: 
(1) general and Congress symposia; (2) astronomy, geodesy and geography, geology and mineral resources; (3) meteorology and terrestrial magnetism, oceanography, radio, seismology and volcanology; (4) agriculture, anthropology, animal diseases and botany; (5) entomology, fisheries, forestry and zoology. The Proceedings will be published by the University of Toronto Press, Toronto, Ont., Canada, price 20 dollars.

\section{Journal of Applied Mechanics}

The Applied Mechanics Division of the American Society of Mechanical Engineers will publish a Journal of Applied Mechanics beginning on March 1935. The technical editor will be J. M. Lessells, Swarthmore, Pa., U.S.A., who will have the assistance of several distinguished authorities on applied mechanics. The Journal will appear four times each year in issues containing about eighty pages each. It will consist of original papers in general mechanics, elasticity, hydrodynamics, aerodynamics, strength of materials and thermodynamics, similar to those published during the last few years in the Transactions of the Applied Mechanics Division of the Society. The price will be five dollars for non-members of the Society for annual subscription, to be sent to A.S.M.E., Applied Mechanics Journal Fund, 29 West 39th Street, New York, N.Y., U.S.A.

\section{The Physical Society's Exhibition}

THE twenty-fifth annual exhibition of scientific instruments and apparatus, arranged by the Physical Society, will be held on January $1-3$ at the Imperial College of Science and Technology, Imperial Institute Road, South Kensington, S.W.7. The leading manufacturers of scientific instruments will be exhibiting their latest products in the Trade Section. The Research and Experimental Section will contain contributions from most of the important research laboratories in Great Britain, and there will be a special sub-section devoted to experiments of educational interest. In addition, the work submitted for the craftsmanship competition by apprentices and learners will be on view. Discourses will be delivered each day at 8 p.m. as follows: January 1, Dr. B. Wheeler Robinson, "The Architecture of Molecules"; January 2, Dr. C. V. Drysdale, "The Problem of Ether Drift" ; January 3, Dr. H. Spencer Jones, M.A., "Giant Telescopes". Members of institutions and scientific societies may obtain tickets from their secretaries; tickets may also be obtained direct from the Exhibition Secretary, 1, Lowther Gardens, Exhibition Road, S.W.7. No tickets will be required on January 3.

\section{Announcements}

Mr. Mervyn O'Gorman will read a paper entitled "Bringing Science into the Road Traffic Problem" before the British Science Guild at the Royal Society of Arts, John Street, Adelphi, London, W.C.2, on December 19, at 5 p.m. The paper will be followed by a discussion.

THE following appointments have recently been made by the Secretary of State for the Colonies:
C. B. Gibbins, to be agricultural assistant, Coffee Experimental Station, Moshi, Tanganyika; S. G. Wilson, to be veterinary officer, Nyasaland; A. C. Shill, marketing officer, fruit and vegetable trades of the Leeward and Windward Islands, to be adviser in agricultural marketing and controller of agricultural exports, Malta; T. H. C. Taylor, late entomologist, Coconut Committee, Fiji, to be assistant entomologist, Agricultural Department, Uganda.

The Royal Academy Exhibition of British Art in Industry will be opened on January 5 and will close early in March. In connexion with the Exhibition, a panel of lecturers has been organised who are prepared to visit schools, works, etc., to lecture on cognate subjects. Further information can be obtained from the Secretary, Royal Academy of Arts, Piccadilly, London, W.1.

IN the list of British representatives present at the opening of the Maison de Chimie in Paris (Nature, Dec. 8, p. 868) it should have been stated that Mr. Edwin Thompson was present in his capacity as president of the Society of Chemical Industry.

Applicatrons are invited for the following appointments, on or before the dates mentioned :-A lecturer in botany in the University of Western Australia--The Agent-General for Western Australia, Savoy House, Strand, London (Dec. 18). An assistant in the M.B. classes and in dental metallurgy at Guy's Hospital Medical School-Prof. C. S. Gibson, Guy's Hospital Medical School, London, S.E.I (Dec. 19). A technical assistant in the War Department Establishment-The Superintendent, Signals Experimental Establishment, Woolwich Common, S.E.18 (Dec. 19). A teacher of metallurgy at the Municipal Technical College, Coventry-The Director of Education, Council House, Coventry (Dec. 21). Two agricultural advisory officers to the Norfolk County Council-The Clerk, The Shirehouse, Norwich (Dec. 22). A lecturer in electrical engineering at West Ham Municipal College, Romford Road, E.15--The Principal (Dec. 31). A demonstrator in chemistry at King's College, Strand, London, W.C.2-The Secretary (Jan. 1). A professor of electrical engineering at the College of Engineering, Guindy, MadrasThe High Commissioner for India, General Department, India House, Aldwych, London, W.C.2 (Jan. 4). A University lecturer in zoology at the University of Cambridge-F. T. Brooks, Botany School, Cambridge (Jan. 7). A director of forestry in the Irish Free State-The Secretary, Irish Land Commission (Forestry), 24, Upper Merrion Street, Dublin (Jan. 31). An investigator for metallurgical research at Cambridge--Prof. R. S. Hutton, University Metallurgy Laboratories, Pembroke Street, Cambridge. A professor of hydraulic engineering and a professor of mechanical engineering at the National Chekiang University, Hangchow-Universities China Committee, 91, Gower Street, London, W.C.1. A junior investigator at the British Non-Ferrous Metals Research Association-The Secretary, B.N.F.M.R.A., Regnart Buildings, Euston Street, N.W.l. 